dr hab.inż. Stanistaw Janusz Cieślakowski, prof. UT-H

Uniwersytet Technologiczno-Humanistyczny w Radomiu

\title{
Problem dłuższego przejazdu szybkich pociągów przez stacje
}

\author{
W pracy obliczono wartości niekorzystnego wydtużenia czasu przejazdu pociagów \\ przez stacje na liniach kolejowych dużych prędkości, spowodowane zmianq toru \\ wjazdowego.
}

\section{WSTĘP}

Aktualnie można zauważyć dynamiczny rozwój kolei dużych prędkości, o czym świadczy zwiększająca się długość linii i wielkość ruchu oraz stale wzrastający udział w rynku.

Największy udział w rynku przewozów pasażerskich w Europie ma transport drogowy, wykonujący ponad $83 \%$ pracy przewozowej w krajach Unii Europejskiej. Transport lotniczy realizuje $8 \%$ wszystkich przewozów, a transport kolejowy 6,2\%. Prawie 25\% (104,1 mld pas. $\mathrm{km}$ ) podróży kolejowych realizowana jest $\mathrm{w}$ Europie przez koleje dużych prędkości [4].

W 2011 roku Komisja Europejska przyjęła tzw. Biała Księgę [9]. Jest to dokument strategiczny warunkujący rozwój europejskiego transportu. Zgodnie z nim podstawy konkurencyjności Europy ma-ją wynikać z dużej mobilności i nowoczesnej technologii transportu. W związku z tym należy przebudować europejską gospodarkę na niskoemisyjna, mało zależną od ropy naftowej i ograniczyć liczbę wypadków w transporcie do zera. Jedną z metod realizacji strategii ma być utworzenie ogólnoeuropejskiej sieci kolei dużych prędkości.
Do 2050 roku ma zostać wybudowana sieć kolei dużych prędkości obejmujących całą Unię Europejską.

Do 2030 roku ma nastapić potrojenie długości tych linii. Przeważająca część podróży na średnie odległości ma się odbywać koleją. Przyjęto, że ponad 50\% towarów na średnie odległości ma być transportowana koleją lub za pomocą żeglugi śródlądowej. Te środki transportu generują najniższe koszty zewnętrzne, czyli te które nie są ponoszone bezpośrednio przez sprawcę (wypadki komunikacyjne, zanieczyszczenie środowiska, zajętość terenu).

Aktualnie wg Eurostatu 86\% przewozów pasażerskich w Polsce odbywa się samochodem, $8 \%$ autobusami, a $6 \%$ koleją.

Według wskazań Białej Księgi w Polsce jednym z najważniejszych zadań będzie program inwestycji kolejowych w tym budowy kolei dużych prędkości.

Koleje dużych prędkości na średnich odległościach do $500 \mathrm{~km}$ uważane są za najszybszy środek transportu.

Przewaga kolei dużych prędkości wobec samolotu wynika $\mathrm{z}$ dogodnego położenia dworców w centrach 
miast i z unikania długich procedur bezpieczeństwa na lotniskach. Podróż lotnicza pomiędzy miastami wojewódzkimi: Gdańskiem, Wrocławiem, Krakowem, Katowicami, Poznaniem, Szczecinem, Bydgoszczą i Rzeszowem, a Warszawą trwa brutto (wliczając dojazd, odprawę, oczekiwanie na lot, sam lot, oczekiwanie na dowóz do terminalu, dojazd do miejsca przeznaczenia) minimum trzy godziny. Natomiast już obecnie klasyczny pociag przejeżdża trasy pomiędzy Warszawa a Poznaniem, Krakowem i Katowicami w czasie krótszym niż trzy godziny [10].

Na dystansie 100-150 km koleje dużych prędkości mają przewagę konkurencyjną nad samochodem. Konkurencyjność ta wynika z większej prędkości ruchu oraz $\mathrm{z}$ ominięcia strefy kongestii $\mathrm{w}$ miastach $\mathrm{i}$ na ich granicach $[3,5,6]$.

Pojęcie dużych prędkości definiowane jest w skonsolidowanej dyrektywie 2008/57 jako minimum $250 \mathrm{~km} / \mathrm{h}$ lub $300 \mathrm{~km} / \mathrm{h}$ w odpowiednich okolicznościach oraz $200 \mathrm{~km} / \mathrm{h}$ na liniach zmodernizowanych.

\section{PODZIAL SIECI KOLEJOWEJ POD WZGLĘDEM TECHNICZNYM}

Sieć kolejowa PKP Polskie Linie Kolejowe S.A. jest to układ połączonych ze sobą linii kolejowych zarządzanych przez PKP PLK S.A.

Linia kolejowa jest to droga kolejowa mająca początek i koniec wraz z przyległym pasem gruntu, na którą składają się odcinki linii a także budynki, budowle i urządzenia przeznaczone do prowadzenia ruchu kolejowego wraz z zajętymi pod nie gruntami. Punkty początkowe i końcowe linii kolejowych ustala Zarząd PKP PLK S.A.

Linie kolejowe dzielą się na odcinki, szlaki i odstępy. Odcinek jest to część linii kolejowej zawarta między sąsiednimi stacjami węzłowymi, albo między punktem początkowym lub końcowym linii kolejowej i najbliższą stacją węzłową.

Szlak jest to część linii kolejowej między:

- dwoma sąsiednimi posterunkami zapowiadawczymi,

- ostatnim posterunkiem zapowiadawczym i końcowym punktem linii.

Odstęp jest to część toru szlakowego między:

- posterunkiem zapowiadawczym, a najbliższym posterunkiem odstępowym (bocznicowym) lub semaforem odstępowym blokady samoczynnej,

- dwoma kolejnymi posterunkami odstępowymi (bocznicowymi),

- posterunkiem odstępowym i bocznicowym,

- dwoma kolejnymi semaforami odstępowymi blokady samoczynnej dla tego samego kierunku jazdy przy danym torze [7].

\section{POSTERUNKI RUCHU I PUNKTY EKSPE- DYCYJNE}

Posterunek ruchu służy do bezpiecznego i sprawnego prowadzenia ruchu kolejowego. Posterunki ruchu dzielą się na następcze i pomocnicze. Posterunek następczy służy do regulacji następstwa jazdy pociagów w ten sposób, ze pozwala na przejazd lub odjazd pociagu tylko wówczas, gdy tor przyległe-go odstępu lub szlaku do tego posterunku jest wolny. Posterunki następcze dzielą się na posterunki: zapowiadacze, bocznicowe i odstępowe.

Posterunek zapowiadawczy jest to posterunek mający możliwość zmiany kolejności jazdy pociągów wyprawianych na tor szlakowy przyległy do tego posterun$\mathrm{ku}$.

Do posterunków zapowiadawczych należą stacje i posterunki odgałęźne.

Stacja jest to posterunek zapowiadawczy, w obrębie którego, oprócz toru głównego zasadniczego, znajduje się co najmniej jeden tor główny dodatkowy. Pociagi mogą rozpoczynać i kończyć jazdę, krzyżować się i wyprzedzać, jak również zmieniać skład lub kierunek jazdy. Duże stacje moga być podzielone na rejony stanowiące osobne posterunki zapowiadawcze. Stacja, na której układ torów umożliwia jedynie krzyżowanie i wyprzedzanie pociagów, nazywa się mijanką. Pod względem ruchu pociagów rozróżnia się stacje:

a) krańcowe, tj. początkowe i końcowe dla danej relacji pociagu,

b) pośrednie, które znajdują się między stacjami krańcowymi.

Stacje, na których łączą się szlaki z trzech lub więcej kierunków, nazywamy stacjami węzłowymi. Zespół stacji i posterunków ruchu sąsiadujących ze sobą nazywa się węzłem kolejowym.

Posterunek odgałęźny urządzony jest poza stacją:

a) w miejscu odgałęzienia linii kolejowej,

b) przy przejściu ze szlaku jednotorowego w dwutorowy i odwrotnie,

c) W miejscu połączenia torów na szlaku.

Posterunek odgałęźny bierze udział w prowadzeniu ruchu wszystkich pociągów kursujących na przyległych szlakach (odstępach).

Granicę pomiędzy szlakiem a posterunkiem zapowiadawczym stanowi:

a) na liniach jednotorowych - semafor wjazdowy tego posterunku,

b) na liniach dwutorowych - miejsce znajdowania się semafora wjazdowego i linia prostopadła do osi torów, w miejscu ustawienia tego semafora. Wyjątkiem są przypadki, gdy granica między poszczególnymi torami szlakowymi a posterunkiem zapowiadawczym jest różna.

Opisana wyżej sytuacja występuje gdy:

a) tory szlakowe oddalone są od siebie tak, że nie można określić linii prostopadłej do osi torów, w miejscu ustawienia semafora wjazdowego. Wówczas granicą między tym torem szlakowym, przy którym nie ma semafora wjazdowego, a posterunkiem zapowiadawczym jest miejsce znajdujące się przy tym torze od strony 
szlaku w odległości $100 \mathrm{~m}$ przed najbliższym rozjazdem lub skrzyżowaniem,

b) w torze najbliższy rozjazd lub skrzyżowanie znajduje się bliżej szlaku niż rozjazd lub skrzyżowanie w sąsiednim torze osłaniany semaforem wjazdowym. Wówczas granicą między tym torem szlakowym, przy którym nie ma semafora wjazdowego, a posterunkiem zapowiadawczym jest miejsce znajdujące się przy tym torze od strony szlaku w odległości $100 \mathrm{~m}$ przed najbliższym rozjazdem lub skrzyżowaniem,

c) przy torze znajduje się odnoszące się do tego toru urządzenie sygnałowe, za pomocą którego podaje się zezwolenie na wjazd pociagu. Wówczas granicą między tym torem szlakowym a torem posterunku zapowiadawczego jest miejsce usytuowania tego urządzenia.

Posterunek bocznicowy jest to posterunek ruchu urządzony na szlaku przy odgałęzieniu bocznicy, który bierze udział w prowadzeniu ruchu wszystkich pociągów kursujących na przyległych odstępach

i pociagów obsługujących bocznicę. Przyjmowanie pociagów na bocznicę $\mathrm{i}$ wyprawianie ich $\mathrm{z}$ bocznicy odbywa się na zasadach ustalonych dla posterunków zapowiadawczych. Natomiast przepuszczanie innych pociagów na zasadach ustalonych dla posterunków odstępowych.

Posterunek odstępowy jest posterunkiem ruchu urządzanym na szlaku w celu podziału szlaku na odstępy. Posterunek odstępowy reguluje następstwo pociaggów, to jest pozwala na przejazd pociagu przez ten posterunek, gdy następny odstęp jest wolny. Posterunki odstępowe obsługiwane na liniach $\mathrm{z}$ półsamoczynną blokadą liniową nazywają się posterunkami blokowy$\mathrm{mi}$, a na liniach $\mathrm{z}$ telefonicznym zapowiadaniem pociągów posterunkami odstępowymi telefonicznymi. $\mathrm{Na}$ liniach $\mathrm{z}$ samoczynną blokadą liniową funkcje posterunków odstępowych spełniają samoczynne semafory blokady.

Posterunek pomocniczy jest to posterunek urządzony na szlaku przy odgałęzieniu bocznicy, tylko w celu umożliwienia wjazdu pociagu na bocznicę i zgłoszenia, że szlak jest wolny, względnie wyjazdu pociagu z bocznicy. Posterunek pomocniczy nie jest wyposażony w semafory i bierze udział w zapowiadaniu tylko pociaggów obsługujących bocznicę.

$\mathrm{Na}$ sieci PKP PLK S.A. oprócz posterunków ruchu występuja również przystanki osobowe i bocznice kolejowe jako punkty ekspedycyjne.

Przystanek osobowy to miejsce na szlaku, urządzone do wsiadania i wysiadania podróżnych,

w którym rozkładowo zatrzymują się pociagi pasażerskie.

Na przystankach osobowych położonych na szlakach jednotorowych nie wyposażonych w urządzenia blokady liniowej, rozkład jazdy może przewidywać zmianę kierunku jazdy pociagów pasażerskich. Szcze- gółowe zasady dokonywania zmiany kierunku jazdy pociągów pasażerskich określają regulaminy techniczne posterunków przylegających do szlaku, na którym następuje zmiana kierunku jazdy.

Bocznica kolejowa jest drogą kolejową połączoną $\mathrm{z}$ linią kolejową i służącą do wykonywania załadunku i wyładunku wagonów lub wykonywania czynności utrzymaniowych pojazdów kolejowych. Bocznica służy do postoju pojazdów kolejowych oraz przemieszczania i włączania pojazdów kolejowych do ruchu po sieci kolejowej. W skład bocznicy kolejowej wchodzą urządzenia sterowania ruchem kolejowym. Są tam, też inne urządzenia związane $\mathrm{z}$ bezpieczeństwem ruchu kolejowego [7].

\section{BUDOWLE I URZĄDZENIA PRZEZNACZO- NE DO PROWADZENIA RUCHU KOLE- JOWEGO}

Posterunki ruchu wyposażone są w budowle i urządzenia niezbędne do prowadzenia ruchu pociągów i wykonywania pracy manewrowej w sposób bezpieczny, zapewniający regularność i sprawność ruchu kolejowego. Do takich budowli i urząazzeń zalicza się: tory i rozjazdy, urządzenia sterowania ruchem kolejowym i łączności, urządzenia do hamowania staczanych odprzęgów na górkach rozrządowych. Są też, urządzenia ułatwiające wykonywanie czynności ładunkowych, wsiadanie i wysiadanie podróżnych, urządzenia informacji świetlnej i dźwiękowej, oświetlenie itp.

Urządzenia na posterunkach ruchu są obsługiwane przez uprawnionych i wyznaczonych pracowników lub działają samoczynnie.

$\mathrm{Na}$ stacjach tory kolejowe dzielą się na tory: główne, specjalnego przeznaczenia i boczne.

Tory przystosowane do jazd pociagowych nazywają się torami głównymi. Dzielą się one na tory główne zasadnicze i tory główne dodatkowe.

Tory główne będące przedłużeniem torów szlakowych nazywają się torami głównymi zasadniczymi, natomiast pozostałe tory główne torami głównymi dodatkowymi.

Do torów specjalnego przeznaczenia należą: żeberka ochronne, tory dojazdowe do bocznic, komunikacyjne, wyciagowe, bocznicowe.

Inne tory na stacjach są torami bocznymi.

Grupy torów przeznaczone wyłącznie do wjazdu lub wyjazdu pociagów nazywają się grupami przyjazdowymi lub grupami odjazdowymi, do wjazdu i wyjazdu pociagów - grupami przyjazdowo-odjazdowymi, a wyłącznie do rozrządzania pociagów - grupami kierunkowymi [7].

\section{METODA BADAŃ I WYNIKI}

Skrzyżowanie torów i rozjazdy kolejowe stanowią elementy sieci kolejowej. Sieć kolejowa jest układem połączonych ze sobą linii i stacji kolejowych [13].

Skrzyżowanie torów to przecięcie się dwóch torów w 
jednym poziomie bez możliwości przejazdu taboru z jednego toru na drugi.

Natomiast połączeniem torów nazywa się konstrukcję umożliwiającą przejazd taboru kolejowego $\mathrm{z}$ jednego toru na drugi, wykorzystując rozjazdy kolejowe.

Rozjazdy dzieli się:

- $\quad$ zwyczajne,

- podwójne,

- krzyżowe,

- $\quad$ łukowe.

Rozjazdy zwyczajne mają dwa kierunki jazdy:

- po torze zasadniczym,

- po torze zwrotnym.

W zależności od kierunku odgałęzienia rozjazd może być prawostronny lub lewostronny.

W aspekcie geometrycznym rozjazdy dzielimy:

- według promienia łuku toru zwrotnego ( $2500 \mathrm{~m}$, $1200 \mathrm{~m}, 760 \mathrm{~m}, 500 \mathrm{~m}, 300 \mathrm{~m}, 190 \mathrm{~m})$,

- według skosów rozjazdów:

- $\quad$ małym skosie $(1: 26,5 ; 1: 18,5 ; 1: 14 ; 1: 12)$,

- $\quad$ skosie zasadniczym (1:9),

- dużym skosie $(1 ; 7,5 ; 1: 6,6 ; 1: 4,8)$.

W aspekcie konstrukcyjnym rozjazdy dzieli się według szyn użytych do budowy rozjazdu:

- $69 \mathrm{E} 1$,

- $49 \mathrm{E} 1$.

Droga zwrotnicowa składa się $\mathrm{z}$ torów prostych lub położonych w łukach poziomych, w których zlokalizowane są rozjazdy i skrzyżowania torów, umożliwiające przejazd $\mathrm{z}$ jednych na inne.

Układając rozjazdy w drogach zwrotnicowych, należy zapewnić bezpieczny oraz płynny przejazd pociagów. Spełnienie tych warunków wymaga układania wstawek prostych o określonej długości między sąsiednimi rozjazdami [11,13].

Do badań wybrano mała stację pośrednią z czterema torami głównymi i dwoma torami bocznymi.

Do konstrukcji głowicy stacyjnej zastosowano następujące rozjazdy:

- $\quad 60$ E $1-2500-1: 26,5$,

- 60 E $1-1200-1: 18,5$,

- 60 E $1-500-1: 12$,

- 60 E $1-300-1: 9$.

Na długość głowicy stacyjnej składa się długość drogi zwrotnicowej i długość przejść trapezo-wych $[1,2,12]$.

W pierwszym przypadku obliczono długość głowicy stacyjnej zbudowanej z rozjazdów o skosie zasadniczym 60 E $1-300$ - 1:9 (układ podstawowy).

W drugim przypadku między torem bocznym a głównym dodatkowym, zlokalizowany był rozjazd 60 E 1 300 - 1:9, między torem głównym dodatkowym a zasadniczym oraz w przejściu trapezowym zlokalizowane były rozjazdy 60 E $1-500-1: 12$.

Trzeci przypadek różnił się od drugiego tym, że w przejściu trapezowym zlokalizowane były rozjazdy 60 E $1-1200-1: 18,5$.
Czwarty przypadek różnił się od trzeciego tym, że w przejściu trapezowym zlokalizowano rozjazdy $60 \mathrm{E} 1$ $-2500-1: 26,5$.

Dopuszczalne prędkości pociągów w torach zwrotnych rozjazdów są następujące dla poszczególnych promieni rozjazdów:

$$
\begin{array}{lll}
\text { - } & \mathrm{R}=300 \mathrm{~m} & \mathrm{~V}=40 \mathrm{~km} / \mathrm{h}, \\
\text { - } & \mathrm{R}=500 \mathrm{~m} & \mathrm{~V}=60 \mathrm{~km} / \mathrm{h}, \\
\mathrm{R}=1200 \mathrm{~m} & \mathrm{~V}=100 \mathrm{~km} / \mathrm{h}, \\
& \mathrm{R}=2500 \mathrm{~m} & \mathrm{~V}=130 \mathrm{~km} / \mathrm{h} .
\end{array}
$$

Dla kolei dużych prędkości, gdzie należy liczyć się z prędkością $\mathrm{V}=250 \mathrm{~km} / \mathrm{h}$, najbardziej odpo-wiednimi rozjazdami w przejściach trapezowych są rozjazdy 60 E $1-2500-1: 26,5$, dla których prędkość pociagów na odgałęzienie po torze zwrotnym przekracza połowę prędkości po torze zasadniczym [8].

Z badań wynika, że w pierwszym przypadku długość głowicy była najkrótsza, a w czwartym naj-dłuższa.

W pierwszym przypadku długość stacji układu podstawowego wyniosła $1550,8 \mathrm{~m}$.

W drugim przypadku długość stacji wyniosła 1789,6 $\mathrm{m}$.

W trzecim przypadku długość stacji wyniosła 2012,4 $\mathrm{m}$.

W czwartym przypadku długość stacji wyniosła 2290,4 m.

Czas przejazdu pociągów na wprost przez stacje dla pierwszego, drugiego, trzeciego i czwartego wariantu konstrukcji wyniósł odpowiednio: 23, 26, 29, $33 \mathrm{~s}$.

Często jednak konieczny jest przejazd pociągów nie po torze głównym zasadniczym będącym przedłużeniem toru szlakowego, po którym jedzie pociag, a po torze głównym zasadniczym sąsiednim.

Może to być spowodowane przez następujące przyczyny:

- $\quad$ planowe roboty torowe na szlaku lub na stacji,

- uszkodzenie torów szlakowych lub stacyjnych,

- awaryjne naprawy torów,

- awarie zasilania torów szlakowych lub stacyjnych,

- $\quad$ awaryjne naprawy sieci trakcyjnej na szlaku lub stacji, awarie urządzeń sterowania ruchem, awaryjne naprawy urządzeń sterowania ruchem, awarie pociągów na szlaku lub stacji, wykolejenie pociągów na szlaku lub stacji, zapełnienie stacji pociagami.

Wówczas czas przejazdu pociagów przez stacje wydłuża się.

Czas ten składa się wówczas z następujących czasów składowych:

- czasu na hamowanie pociagu,

czasu na przejazd przez stację ze stałą prędkością, równą prędkości jazdy przez rozjazd na odgałęzienie, 


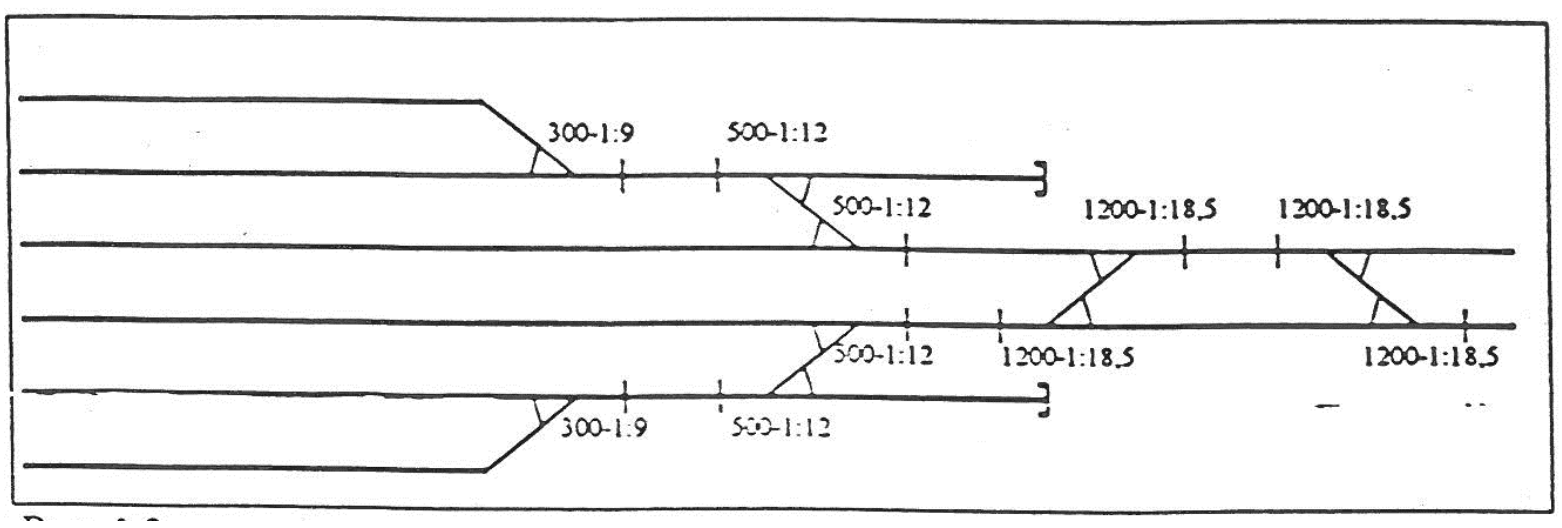

Rys. 1 Głowica stacyjna

- $\quad$ czasu na rozpędzanie pociagu.

Obliczenia przeprowadzono dla wartości przyspieszenia $i$ opóźnienia pociągów równego 0,6 $\mathrm{m} / \mathrm{s} 2$.

Przy tym sposobie przejazdu dla pierwszego, drugiego, trzeciego i czwartego wariantu konstrukcji stacji czasy przejazdu pociagów kształtowały się odpowiednio następująco: 223 s, 171 s, 114 s. 92.

Badania przeprowadzono na przykładzie głowicy stacyjnej przedstawionej na rys. 1 .

\section{WNIOSKI}

Z wykonanej pracy wynikają następujące wnioski:

1. Wydłużenie czasu przejazdu pociagów spowodowane jazdą na odgałęzienie jest następujące:

- dla pierwszego wariantu konstrukcji stacji $201 \mathrm{~s}$,

- dla drugiego wariantu konstrukcji stacji $145 \mathrm{~s}$,

- dla trzeciego wariantu konstrukcji stacji $85 \mathrm{~s}$,

- dla czwartego wariantu konstrukcji stacji 59 s.

2. Na klasycznym - najkrótszym układzie torowym stacji wydłużenie czasu jest największe.

3. Na najdłuższym - najnowocześniejszym układzie torowym stacji wydłużenie czasu jest najmniejsze.

\section{BIBLIOGRAFIA}

1. Bałuch H.: Uktady geometryczne połqczeń torów. WKiE Warszawa 1989.

2. Cieślakowski S. J.: Stacje kolejowe. WKi亡 Warszawa 1992.

3. De Rus G (red.).: Economic. Analysis of High Speed Rail in Europoe. Fundacja BBVA. Bilbao. 2009.

4. EU transport in figures. Statistal Pocketbook 3011. European Commission. Belgia 2011.

5. High Speed in Europe. A sustainable link between citizens. European Commission. 2010.

6. High Speed Rail \& Sustainability. Report. UIC. 2011.

7. Instrukcja prowadzenia ruchu pociagów. PKP PLK S.A. Warszawa 2008.

8. Instrukcja /d - 4: Instrukcja o oględzinach, badaniach technicznych i utrzymaniu rozjazdów. PKP PLK S.A. Warszawa 2014.

9. Komisja Europejska. 2011. Biała Ksiega. Plan utworzenia jednolitego europejskiego obszaru transportu dażenie do osiagnięcia konkurencyjnego i zasobooszczędnego systemu transportu. KOM (2011) 144. Bruksela.

10. Mincewicz J.: KDP - przede wszystkim dobra i bezpieczna infrastruktura. Infrastruktura transportu $4 / 2013$.

11. Rozporzqdzenie Ministra Transportu i Gospodarki Morskiej w sprawie warunków technicznych, jakim powinny odpowiadać budowle kolejowe $i$ ich usytuowanie. Dz. U.1998, nr151, poz. 987.

12. Sysak I. i inn.: Drogi kolejowe. PWN Warszawa 1986.

13. Ustawa z 28 marca 2003r. o transporcie kolejowym.(Dz. U. $2003 \mathrm{nr}$ 86, poz.789). 